\title{
Comparative Biologies of the Cryptic, Sympatric Species, Trupanea bisetosa and T. nigricornis (Diptera: Tephritidae) in Southern California
}

\author{
KHOUZAMA M. KNIO, RICHARD D. GOEDEN, AND DAVID H. HEADRICK
}

Department of Entomology, University of California, Riverside, CA 92521

\begin{abstract}
Ann. Entomol. Soc. Am. 89(2): 252-260 (1996)
ABSTRACT The biologies of the sympatric, cryptic species, Trupanea nigricornis (Coquillett), a flower head-infesting fruit fly attacking a wide range of hosts in 8 tribes, 33 genera, and at least 71 species of Asteraceae, and T. bisetosa (Coquillett), an oligophage attacking only 6 hosts in 4 genera of the tribe Heliantheae, are described and compared. A major biological distinction between these species was their ovipositional behavior, whereby females oviposited different numbers of eggs at different sites in different developmental stages of flower heads of their hosts. The larvae of these species showed minor differences in their feeding behaviors, and their puparia were formed and located similarly in host flower heads. Development from egg to adult under field conditions lasted up to $35 \mathrm{~d}$ for each species. These species showed subtle differences in their courtship and mating behaviors, and substantial differences in the daily timing of courtship.
\end{abstract}

KEY WORDS Trupanea, cryptic species, host specificities, mating behavior, phenology, sympatric species

THE FLOWER HEAD-infesting fruit flies, Trupanea bisetosa (Coquillett) and T. nigricornis (Coquillett), occur in sympatry in southern California (Foote et al. 1993). These species are considered cryptic because adults of both sexes share a close morphological resemblance (Cavender and Goeden 1983) and their immature stages essentially are indistinguishable (Knio et al. 1996). However, the 2 species do show major ecological differences. T. bisetosa is an oligophage restricted to wild sunflowers, Helianthus spp., and to 2 other genera in the tribe Heliantheae (Asteraceae); whereas T. nigricomis is a generalist, infecting a wide range of host plants belonging to at least 8 tribes, and 33 genera of Asteraceae (Goeden 1985, 1992; unpublished data).

Because these 2 tephritids are closely related, cryptic, sympatric, presumably sibling species and yet show different modes of herbivory, they offer an opportunity for study of the biological, morphological, and ecological features that separate them. Results of our comparative studies on the morphology, biology, ecology, and behavior of T. bisetosa and $T$. nigricornis ellucidate the nature of oligophagy/polyphagy in these species.

The biology of $T$. bisetosa was documented in part by Cavender and Goeden (1982, 1983); the biology of $T$. nigricornis has not been described.

\section{Materials and Methods}

Samples of flower heads of $T$. nigricormis and $T$. bisetosa host plants were collected at each of 22 desert and interior-valley locations in southern $\mathrm{Cal}$ ifornia during 1987-1992. The host plants of $T$. nigricomis sampled were Encelia farinosa Gray, $E$. fructescens Gray, E. virginensis A. Nelson, Haplopappus acradenius (Greene) Hall, Viguiera deltoidea Gray, and Geraea viscida (Gray) Blake. The host plants of $T$. bisetosa sampled were Helianthus annuus L., $H$. niveus (Bentham), and Geraea canescens Torrey \& Gray.

Each plant sample consisted of a liter plastic bag containing 100-700 mature flower heads. Flower heads sampled were picked at random from several plants at each collection site. They were transported to the laboratory and stored in the refrigerator until dissection. The total number of heads dissected to obtain both subsamples was recorded to calculate percentage of infestation. A random subsample of 25 infested heads from each sample was dissected to determine the following 5 parameters: (1) the presence and stages of $T$. nigricomis or T. bisetosa, (2) the locations and positions of the different immature stages in the flower heads, (3) the number of achenes damaged by larval feeding, (4) the stage of each flower head, and (5) size variables, including the dry weight. Thirty, individual, fully grown, 3rd instars removed from the dissected heads were held in separate glass shell vials in humidity chambers at $76 \% \mathrm{RH}$ at $27 \pm 1^{\circ} \mathrm{C}$ to determine the length of time required for pupariation and adult emergence.

The remaining flower heads in every sample were counted and placed in glass-topped, sleeve 
Table 1. Mean $\pm \mathrm{SE}$ of the flower-head characteristics of the host plants of $T$. bisetosa and $T$. nigricornis in southern California

\begin{tabular}{|c|c|c|c|c|c|c|}
\hline $\begin{array}{l}\text { Host plant } \\
\text { species }\end{array}$ & $\begin{array}{c}\text { No. } \\
\text { heads }\end{array}$ & Diam, mm & Length, mm & $\begin{array}{l}\text { Receptacle } \\
\text { width, mm }\end{array}$ & No. achenes/head & Dry wt of $25, \mathrm{~g}$ \\
\hline \multicolumn{7}{|c|}{ T. bisetosa } \\
\hline H. nivens & 50 & $\begin{array}{l}11.8 \pm 0.2 c \\
(10.5-14.7)\end{array}$ & $\begin{array}{l}13.6 \pm 0.2 c \\
(11.6-15.1)\end{array}$ & $\begin{array}{l}9.1 \pm 0.4 \mathrm{~d} \\
(6.8-11.2)\end{array}$ & $\begin{array}{l}46 \pm 1 b c \\
(28-74)\end{array}$ & $\begin{array}{l}4.4 \pm 0.2 \\
(4.2-4.5)\end{array}$ \\
\hline G. canescens & 175 & $\begin{array}{r}12.1 \pm 0.6 \mathrm{c} \\
(7.7-16.8)\end{array}$ & $\begin{array}{c}13.5 \pm 0.2 \mathrm{c} \\
(10-16.7)\end{array}$ & $\begin{array}{l}5.7 \pm 0.2 \mathrm{c} \\
(3.8-7.5)\end{array}$ & $\begin{array}{l}46 \pm 5 b c \\
(22-86)\end{array}$ & $\begin{array}{l}4.6 \pm 0.6 \\
(2.4-6.5)\end{array}$ \\
\hline H. annutus & 200 & $\begin{array}{r}19.2 \pm 0.2 f \\
(8.5-23.5)\end{array}$ & $\begin{array}{c}19.1 \pm 0.9 \mathrm{c} \\
(10-31.5)\end{array}$ & $\begin{array}{c}10.8 \pm 0.2 \mathrm{e} \\
(7-16.7)\end{array}$ & $\begin{array}{c}120 \pm 3 f \\
(83-130)\end{array}$ & $\begin{array}{c}21 \pm 1 \\
-\end{array}$ \\
\hline \multicolumn{7}{|c|}{ T. nigricormis } \\
\hline H. acradenitus & 125 & $\begin{array}{l}3.7 \pm 0.2 \mathrm{a} \\
(2.5-6)\end{array}$ & $\begin{array}{r}1.2 \pm 0.4 b \\
(9.4-15.2)\end{array}$ & $\begin{array}{l}2.1 \pm 0.1 \mathrm{a} \\
(1.3-3.3)\end{array}$ & $\begin{array}{c}1.5 \pm 1 \mathrm{a} \\
(9-22)\end{array}$ & $\begin{array}{l}0.5 \pm 0.1 \\
(0.4-0.8)\end{array}$ \\
\hline E. fructescens & 425 & $\begin{array}{c}12.9 \pm 0.4 \mathrm{~d} \\
(8-18.5)\end{array}$ & $\begin{array}{c}15 \pm 0.4 c \\
(9-24)\end{array}$ & $\begin{array}{c}5.5 \pm 0.2 \mathrm{c} \\
(3-8.4)\end{array}$ & $\begin{array}{c}40 \pm 2 b \\
(19-75)\end{array}$ & $\begin{array}{l}6.1 \pm 0.5 \\
(3.2-9.3)\end{array}$ \\
\hline V. deltoidea & 150 & $\begin{array}{c}10.4 \pm 0.3 b \\
(6.7-13)\end{array}$ & $\begin{array}{c}11.4 \pm 0.3 \mathrm{ab} \\
(8-13.9)\end{array}$ & $\begin{array}{l}4.1 \pm 0.1 b \\
(2.5-5.4)\end{array}$ & $\begin{array}{l}50 \pm 5 c \\
(28-93)\end{array}$ & $\begin{array}{l}3.3 \pm 0.5 \\
(2.4-5.5)\end{array}$ \\
\hline E. farinosa & 425 & $\begin{array}{c}11.9 \pm 0.2 \mathrm{c} \\
(8.7-16.4)\end{array}$ & $\begin{array}{c}10.9 \pm 0.2 \mathrm{a} \\
(8.3-15)\end{array}$ & $\begin{array}{l}4.3 \pm 0.1 b \\
(2.5-6.4)\end{array}$ & $\begin{array}{l}62 \pm 2 \mathrm{~d} \\
(28-112)\end{array}$ & $\begin{array}{l}3.3 \pm 0.1 \\
(2.2-4.3)\end{array}$ \\
\hline E. virginensis & 225 & $\begin{array}{r}16.5 \pm 0.4 \mathrm{e} \\
(10-22.3)\end{array}$ & $\begin{array}{l}14.5 \pm 0.3 c \\
(19.4-18.3)\end{array}$ & $\begin{array}{l}8.6 \pm 0.2 \mathrm{~d} \\
(5.6-13.4)\end{array}$ & $\begin{array}{l}90 \pm 6 e \\
(45-152)\end{array}$ & $\begin{array}{c}8.4 \pm 0.6 \\
(4-10)\end{array}$ \\
\hline
\end{tabular}

Means followed by the same letter are not significantly different at the $95 \% \mathrm{CL}$.

cages ( 34 by 32 by $35 \mathrm{~cm}$ ) in the insectary at $60 \%$ $\mathrm{RH}$ and a photoperiod of 12:12 (L:D) from 0500 to 1700 hours. The numbers and identities of the emerging insects were recorded.

The adults of $T$. nigricornis were observed in nature on $E$. farinosa, their most common native, wild host in southern California, during AprilJune, 1988-1991. The activities of the flies were observed and recorded at different times throughout the day. The behavior of newly emerged adults was also observed in glass-topped sleeve cages (34 by 32 by $35 \mathrm{~cm}$ ) in the laboratory (above conditions). The flies were given a yeast hydrolysate diet (sucrose : yeast hydrolysate : water) (7:4:10) (Tsiropoulos 1978), in addition to water, honey, and bouquets of flower heads of $E$. farinosa, the stems of which were immersed in water. Oviposition, courtship and mating behaviors were studied by observing flies in sleeve cages and at field sites.

Voucher specimens of immature stages of $T$. nigricormis and $T$. bisetosa are stored in the research collections of D.H.H. and Jeffrey A. Teerink (Department of Entomology, University of California, Riverside). Voucher specimens of adults reside in the research collection of R.D.G. Means \pm SE are provided throughout the article.

\section{Results}

\section{Trupanea bisetosa (Coquillett)}

Host-Plant Range and Distribution. Trupanea bisetosa is an oligophage restricted to wild sunflowers, Helianthus spp., and to 2 other genera in the tribe Heliantheae, Baileya and Geraea (Goeden $1985,1992)$. These are found throughout southern California. The geographic range of $T$. bisetosa extends throughout the western half of the United
States from North Dakota to Texas (Foote et al 1993).

Host-Plant Characteristics. The most abundant host species of $T$. bisetosa, $H$. annuus, blooms throughout the year in the absence of frost and thus serves as a continuous resource in southern California. The remainder of its hosts are restricted in their distribution and have short blooming periods $(1-2 \mathrm{mo})$ in the early spring. The flower head characteristics for $T$. bisetosa host-plant species are summarized in Table 1. Among T. bisetosa hosts, $H$. niveus and $G$. canescens flower heads were small $(\approx 12 \mathrm{~mm})$ and those of $H$. annuus were large (19.2 mm). Among T. bisetosa hosts, H. niveus and G. canescens had shorter flower heads with smaller receptacle diameters and lower dry weight than $H$. annuus (Table 1). Accordingly, H. niveus and G. canescens averaged $46 \pm 1$ and $46 \pm 5$ seeds per flower head, respectively, and $H$. annuus averaged $120 \pm 3$ seeds per flower head (Table 1). There was a high correlation between the number of seeds per head and the sizes of the flower heads of these host-plant species. Regression analysis showed that the number of seeds was highly correlated with the diameter of the flower head $(R$, coefficient of correlation $=0.86$ ) and the diameter of the receptacle $(R=0.81)$.

Oviposition. $T$. bisetosa females were observed in the field to walk or fly to closed, preblossom flower heads for oviposition from 0900 hours and actively inspect and probe until sunset at 19001930 hours. They walked on the flower heads, exhibited asynchronous wing supination (as defined by Headrick and Goeden 1995) during initial inspections, and touched the substrate with the proboscis. Females then probed among the florets with the aculeus for $6-30 \mathrm{~s}(n=10)$. However, unlike $T$. nigricomis, they did not pierce the plant 

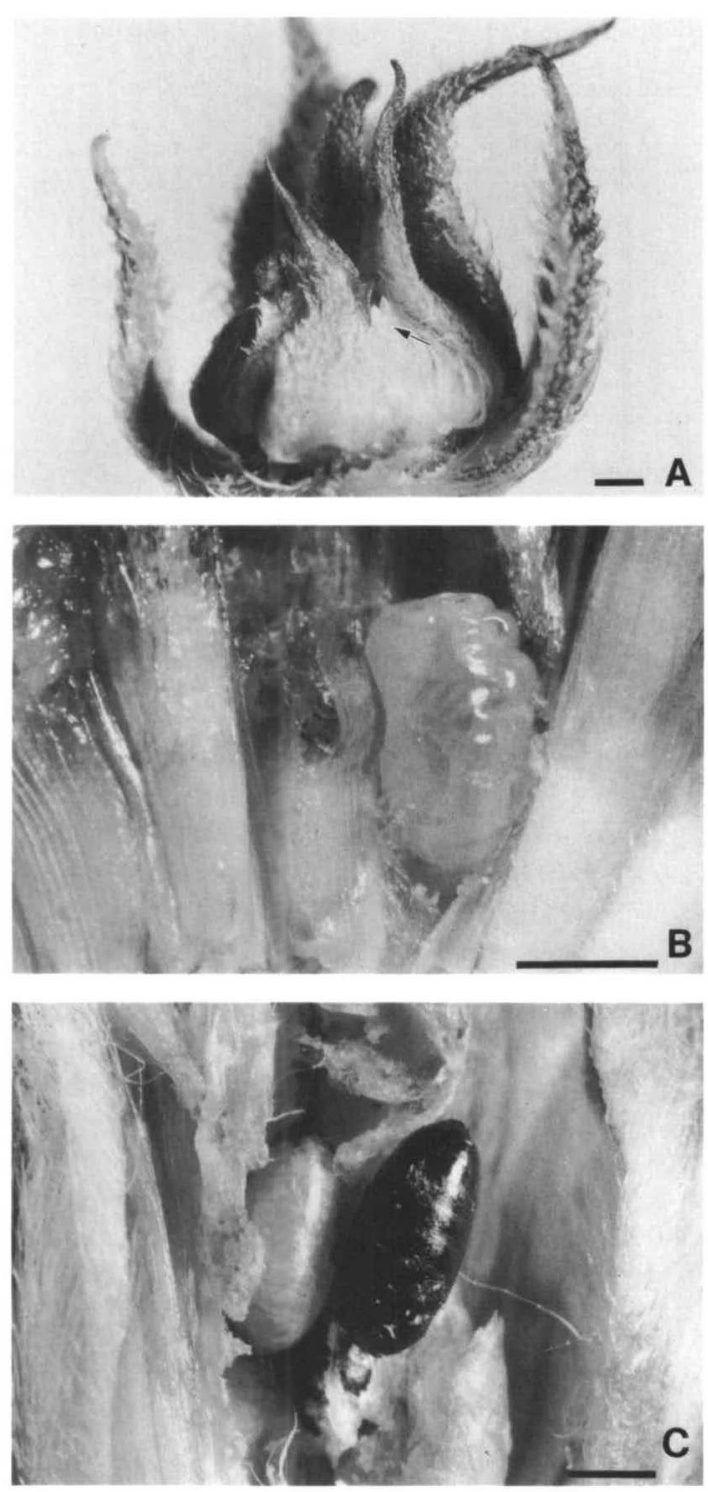

Fig. 1. Life stages of T. bisetosa on Helianthus annuus in southern Califormia. (A) egg, (B) 3rd instar, (C) puparium. Bars $=1 \mathrm{~mm}$.

tissues while probing or ovipositing. Instead, they exserted the aculeus through the spaces between the overlapping bracts at the center of the closed flower head and deposited their eggs on top of or among the immature florets just beneath the bracts.

Oviposition lasted an average of $1.0 \pm 0.1 \mathrm{~min}$ ( $n=15$; range, $0.5-1.5 \mathrm{~min}$ ). Ten of 10 females oviposited in $H$. annuus flower heads that already contained T. bisetosa eggs.

Preimaginal Biology. Preimaginal development lasts up to $35 \mathrm{~d}$ for an individual. A single generation occurred from early March through June in the field.
Egg. Eggs were laid inside closed flower buds just beneath the green involucral bracts (Fig. 1A). The eggs were not inserted into plant tissues, but were loosely placed atop of or among the florets, but well above the ovules. They rested atop or between the closed corollas, parallel and along the long axes of the corollas, or within the open corollas of individual florets. The eggs resting between the florets were lightly glued along part of their egg bodies to the corollas. Dissections of 100 , field-collected, infested heads showed that eggs were deposited either singly or in clusters of 2-6. Most heads (54\%) contained 3-5 eggs, $13 \%$ held 6-8 eggs, $25 \%$ held $1-2$ eggs, and only $8 \%$ held $9-$ 13 eggs. Eggs of T. bisetosa collected from wild sunflower heads directly after oviposition eclosed in $4 \mathrm{~d}(n=20)$.

First Instar. First instars crawled on the distal surfaces of florets after eclosion. Each individual crawled into an open corolla and tunneled downward while feeding.

Second Instar. Second instars tunneled farther into the corollas as they continued feeding, but did not enter or feed in the soft achenes. Four (8.8\%) of 45 second instars became trapped within sticky plant resins while tunneling horizontally across and between florets. Larvae trapped in this manner eventually died.

Third Instar. Third instars continued to tunnel downward in the corollas and into the soft achenes where they fed until the achene was completely destroyed, then they fed on 3-6 adjacent achenes that were also completely or partially destroyed (Fig. 1B). Although most 3rd instars fed while oriented parallel to the long axis of the achenes, $\approx 10 \%$ tunneled parallel to the receptacle, which resulted in damage to 8-9 achenes. The distance 3rd instars of $T$. bisetosa fed above the receptacle varied among the host species. In G. canescens, the larvae fed mainly between 1 and $2 \mathrm{~mm}$ above the receptacle. In the large heads of $H$. annuus, $89 \%$ of the larvae were found between 0.8 and $2 \mathrm{~mm}$ above the receptacle, and only $2 \%$ were found at the surface of the receptacle. No scoring of the receptacle by $T$. bisetosa was observed in $H$. annuus flower heads.

Puparium. Pupariation formation averaged 7.3 $\pm 0.2 \mathrm{~h},(n=8$; range, $6-8 \mathrm{~h})$. The puparium was formed in the larval feeding cavity (Fig. 1C) and was surrounded by and lightly glued to 4-8 damaged achenes or corolla fragments. Some puparia were formed contiguous when $>1$ individual was present in a flower head.

In $H$. annuus, no differences in puparial sizes were detected among flower heads with infestations ranging from 1 to 12 individuals per flower head (Tables 2 and 3).

Analysis of Infestation. Thirty percent of $H$. annuus flower heads contained only 1 larva, $47 \%$ contained 2 or 3 larvae, $13.2 \%$ contained 4 or 5 larvae, $6.6 \%$ contained 6 or 7 larvae, and $\approx 3 \%$ contained 8-12 larvae. There was a moderate corre- 
Table 2. Means \pm SE sizes of $T$. bisetosa and $T$. nigricornis puparia by host plant (range in parentheses)

\begin{tabular}{lccc}
\hline \hline Host plant species & No. & Diam, mm & Length, mm \\
\hline & & $T$. bisetosa & $3.11 \pm 0.01(2.5-3.55) \mathrm{d}$ \\
$H$. annutus & 221 & $1.43 \pm 0.01 \quad(1.2-1.6) \mathrm{d}$ & $2.76 \pm 0.01(2.2-3.25) \mathrm{b}$ \\
& & $T$. nigricornis & $2.84 \pm 0.01(2.16-3.25) \mathrm{c}$ \\
E. farinosa & 31.0 & $1.26 \pm 0.002(1-1.5) \mathrm{a}$ & $2.73 \pm 0.01(2.2-3) \mathrm{b}$ \\
E. fructescens & 270 & $1.28 \pm 0.01 \quad(1-1.55) \mathrm{c}$ & $2.42 \pm 0.03(2.1-2.75) \mathrm{a}$ \\
E. virginensis & 134 & $1.25 \pm 0.003(1-1.35) \mathrm{ab}$ & $2.72 \pm 0.02(2.5-3) \mathrm{b}$ \\
H. acradenius & 28 & $1.22 \pm 0.01 \quad(1-1.25) \mathrm{a}$ & $(2.75-2.75) \mathrm{b}$ \\
V. deltoidea & 37 & $1.25 \pm 0.01 \quad(1.1-1.48) \mathrm{ab}$ & $2.75 \pm 0$ \\
G. viscida & 4 & $1.25 \pm 0 \quad(1.25-1.25) \mathrm{ab}$ & $(2.75 \pm 0$ \\
\hline
\end{tabular}

Means followed by the same letter are not significantly different at the $95 \% \mathrm{CL}$.

lation between the number of larvae present with the size $(R=0.4)$ and the dry weight $(R=0.38)$ of the flower heads of different infested hosts. Smaller flower heads were infested with fewer larvae than large heads. The relatively smaller flower heads of $G$. canescens contained 2-4 T. bisetosa larvae per flower head and those of $H$. niveus contained 1-2 larvae per flower head.

A single larva of $T$. bisetosa destroyed an average of 6.4 achenes in H. annuus and an average of 5.0 achenes in G. canescens (Table 4). There was no significant difference in the amount of achenes damaged in $H$. annuus and $G$. canescens. The number of achenes damaged by a single $T$. bisetosa larva was highly correlated with the diameter $(R=$ 0.99 ) and the dry weight ( $R=0.46)$ of the heads.

Percentage of achenes destroyed per flower head by a single $T$. bisetosa larva was higher (16\%) in the medium-size flower heads of $G$. canescens than the larger heads of $H$. annuus (6\%) (Table 4). Also, it was highly correlated with the diameter $(R$ $=0.91$ ) and dry weight $(0.86)$ of the heads.

Courtship and Mating. Courtship and mating behaviors are summarized in Table 5 . T. bisetosa males displayed aggregation behaviors in the lab- oratory between 0900 and 1400 hours $(n=50)$; these behaviors included abdominal pleural distension and asynchronous supination (Headrick and Goeden 1995). During these displays, males approached females with the pleura remaining distended and continuing their wing display. Males supinated their wings while stationary, but in 16 $(80 \%)$ of 20 observations, they also supinated their wings while walking toward a female (Headrick and Goeden 1995). The male advanced 1 step forward with each supination.

At close proximity to females, males faced them and synchronously supinated their wings forward $90^{\circ}$, then held them still. This short pause was followed by 2 or 3 synchronous supinations to and from the perpendicular. Males then approached females while displaying synchronous, circular, counter-clockwise, rotating motions with their wings until their mouthparts made contact.

Mating was observed only in the laboratory. Two matings were observed from initiation to completion. Females usually flew away or raised their forelegs to fend off approaching males. The duration of these 2 insectary matings were 7 and $8 \mathrm{~min}$.

Table 3. Mean \pm SE sizes of $T$. bisetosa and $T$. nigricornis puparia by infestation rate (range in parentheses)

\begin{tabular}{|c|c|c|c|}
\hline \multirow{2}{*}{ Host plant species } & \multicolumn{3}{|c|}{ No. larvae per flower head } \\
\hline & 1. & $2-3$ & $4+$ \\
\hline \multicolumn{4}{|c|}{ T. bisetosa } \\
\hline \multicolumn{4}{|l|}{ H. annutus } \\
\hline Diam & $1.46 \pm 0.02(1.25-1.55) \mathrm{a}$ & $1.42 \pm 0.01(1.25-1.6) \mathrm{a}$ & $1.44 \pm 0.01(1.2-1.6) \mathrm{a}$ \\
\hline Length & $3.08 \pm 0.04(2.55-3.5) \mathrm{a}$ & $3.14 \pm 0.02(2.8-3.5) \mathrm{a}$ & $3.16 \pm 0.02(2.8-3.55) \mathrm{a}$ \\
\hline$n$ & 29 & 79 & 84 \\
\hline \multicolumn{4}{|c|}{ T. nigricormis } \\
\hline \multicolumn{4}{|l|}{ E. farinosa } \\
\hline Diam & $1.26 \pm 0.01 .(1-1.5) \mathrm{a}$ & $1.25 \pm 0 \quad(1.25-1.3) \mathrm{a}$ & - \\
\hline Length & $2.75 \pm 0.01(2.25-3.25) \mathrm{a}$ & $2.75 \pm 0.01(2.5-3.08) \mathrm{a}$ & - \\
\hline$n$ & 136 & 106 & - \\
\hline \multicolumn{4}{|l|}{ E. fructescens } \\
\hline Diam & $1.32 \pm 0.01(1-1.55) \mathrm{a}$ & $1.27 \pm 0.02(1-1.3) \mathrm{ab}$ & $1.24 \pm 0.02(1-1.48) b$ \\
\hline Length & $2.87 \pm 0.03(2.16-3.25) \mathrm{a}$ & $2.84 \pm 0.03(2.2-3.2) \mathrm{a}$ & $2.84 \pm 0.05(2.5-3.2) \mathrm{a}$ \\
\hline$n$ & 80 & 44 & 19 \\
\hline \multicolumn{4}{|l|}{ E. virginensis } \\
\hline Diam & $1.25 \pm 0 \quad(1.25-1.25) \mathrm{a}$ & $1.24 \pm 0.01(1-1.35) \mathrm{a}$ & $1.23 \pm 0$ \\
\hline Length & $2.81 \pm 0.04(2.75-3) \mathrm{a}$ & $2.71 \pm 0.02(2.2-3) \mathrm{a}$ & $2.72 \pm 0.03(2-3) \mathrm{a}$ \\
\hline$n$ & 8 & 44 & 54 \\
\hline
\end{tabular}

Means followed by the same letter are not significantly different at the $95 \%$ CL. $n$, number of puparia measured. 
Table 4. Mean \pm SE of achenes damaged by $T$. bisetosa and $T$. nigricornis 3rd instars in different host plants

\begin{tabular}{|c|c|c|c|}
\hline \multirow{2}{*}{ Host plant species } & \multirow{2}{*}{ No. larvae } & \multicolumn{2}{|c|}{ Damaged achenes per larva } \\
\hline & & No. & Frequency (\%) \\
\hline \multicolumn{4}{|c|}{ Hosts of $T$. bisetosa } \\
\hline H. annutus & 225 & $6.4 \pm 0.1(3-11) \mathrm{a}$ & $6.3 \pm 0 \quad(2.4-13.8)$ \\
\hline G. canescens & 1.2 & $5.2 \pm 0.2(4-6) \mathrm{a}$ & $16.3 \pm 0.02(9-23)$ \\
\hline \multicolumn{4}{|c|}{ Hosts of $T$. nigricomis } \\
\hline E. farinosa & 225 & $8.8 \pm 0.2(3-16) c$ & $18.2 \pm 0 \quad(7.1-43.5)$ \\
\hline V. deltoidea & 50 & $8.5 \pm 0.5(4-19) b c$ & $21.9 \pm 0.01(9.4-52)$ \\
\hline E. virginensis & 165 & $8 \pm 0.2(4-14) b$ & $10.3 \pm 0 \quad(4-27.1)$ \\
\hline E. fructescens & 225 & $7.9 \pm 0.2(3-16) b$ & $24.3 \pm 0.01(8-58.3)$ \\
\hline H. acradenius & 56 & $7.3 \pm 0.3(3-13) \mathbf{a}$ & $50.6 \pm 0.02(23-83)$ \\
\hline
\end{tabular}

Means followed by the same letter are not significantly different at the $95 \% \mathrm{CL}$.

\section{Trupanea nigricornis (Coquillett)}

Host-Plant Range and Distribution. T. nigricornis is a generalist, infesting a wide range of host plants belonging to at least 8 tribes, 33 genera, and 71 species of Asteraceae (Goeden 1985, 1992; unpublished data). These hosts occur throughout southern California. The geographic range of T. nigricornis extends throughout the western half of the United States from North Dakota to Texas (Foote et al. 1993).

Host-Plant Characteristics. Different host species of $T$. nigricomis bloom at different times of the year, so a constant supply of flower heads is available throughout most of the year. The majority of host-plant species of $T$. nigricomis bloom in the spring (for example, Encelia spp.) or fall (for example, Haplopappus spp.), and for periods of 2-3 mo depending on the amounts of moisture in the soil. The size parameters of the host-plant species of $T$. nigricornis were quantified (Table 1). Haplopappus acradenius flower heads had a mean diameter of $4.0 \mathrm{~mm}, V$. deltoidea averaged $10.0 \mathrm{~mm}$, E. farinosa $12.0 \mathrm{~mm}$, E. fructescens $13.0 \mathrm{~mm}, E$. virginensis $16.5 \mathrm{~mm}$, and G. viscida $21 \mathrm{~mm}$. Among the hosts of T. nigricornis studied, H. acradenius flower heads had the smallest mean receptacle diameter and the lowest mean dry weight, followed by $V$. deltoidea, E. farinosa, E. fructescens, E. virginensis, and G. viscida (Table 1). With respect to the number of achenes per flower head, $H$. acradenius had the lowest mean number $(15 \pm$ 1) followed by $E$. fructescens $(40 \pm 2)$, V. deltoidea $(50 \pm 5)$, E. farinosa $(65 \pm 2)$, G. viscida $(85 \pm$ $2)$, and $E$. virginensis $(90 \pm 6)$.

Oviposition. Oviposition by $T$. nigricornis during field observations began at $\approx 0900$ hours and continued until sunset at 1900-1930 hours. Females moved frequently from one flower head to another by direct flight, by walking along a branch toward the flower head, or by walking between adjacent flower heads. During examination of flower heads females touched their proboscis to the substrate and exhibited wing displays such as asynchronous wing supination (Headrick and Goeden 1995). Probing the tops of the florets was done with the partially extended aculeus. Two to 4 probes occurred during a search period and averaged $32 \pm 3 \mathrm{~s}(n=12$; range, $10-52 \mathrm{~s})$ before oviposition took place. The process of probing was determined (by later dissections) always to result in the piercing of plant tissues. Moreover, females were observed to retract the aculeus, turn around, and feed on the sap exuding from probing wounds. Eggs were oviposited into the soft tissues of the ovules, soft achenes, or corollas of open (preblossom and blossom) flower heads. The long axes of the eggs were parallel or slightly diagonal to the long axes of the florets after oviposition. Egg deposition averaged 2.2 $\pm 0.1 \mathrm{~s}(n=60$; range, $0.6-$ $5.5 \mathrm{~s}$ ). Dissections of $40 \mathrm{E}$. farinosa flower heads collected just after an observed oviposition showed that 35 of $40(87.5 \%)$ of these heads already were infested with $T$. nigricomis preimaginal stages. Moreover, females were observed to oviposit in the same head more than once, either in succession or on returning from adjacent flower heads. Near the end of seasonal flowering by $E$. farinosa, when few open flower heads remained, more eggs per flower head were found than early in the season (10-27 eggs versus $1-5$ eggs per head, respectively).

Preimaginal Biology. Preimaginal development lasts up to $35 \mathrm{~d}$ for an individual. A single generation lasted from late February through late June in the field.

Egg. Field-collected, infested flower heads of $E$. farinosa contained 1-7 eggs per flower head $(n=$ 100) (Fig. 2A). Most flower heads (36\%) contained 1 egg, but 27 and $21 \%$ contained 2 and 3 eggs per flower head, respectively. Eight percent and 5\% contained 4 and 5 eggs, respectively; only 1 and $2 \%$ contained 6 and 7 eggs, respectively. T. nigricomis eggs dissected from $E$. farinosa heads directly after oviposition eclosed in $3.4 \pm 0.1 \mathrm{~d}(n=$ 20 , range, $3-4 d$ ).

First Instar. First instars tunneled into then fed inside the ovules, soft achenes, or tubular corollas. Larvae emerging from eggs inserted in a corolla tunneled downward until they reached the ovule. Those larvae hatching from eggs inserted into an ovule tunneled directly inward to feed, enlarged a cavity, and then tunneled laterally through 1-2 adjacent ovules or soft achenes. 

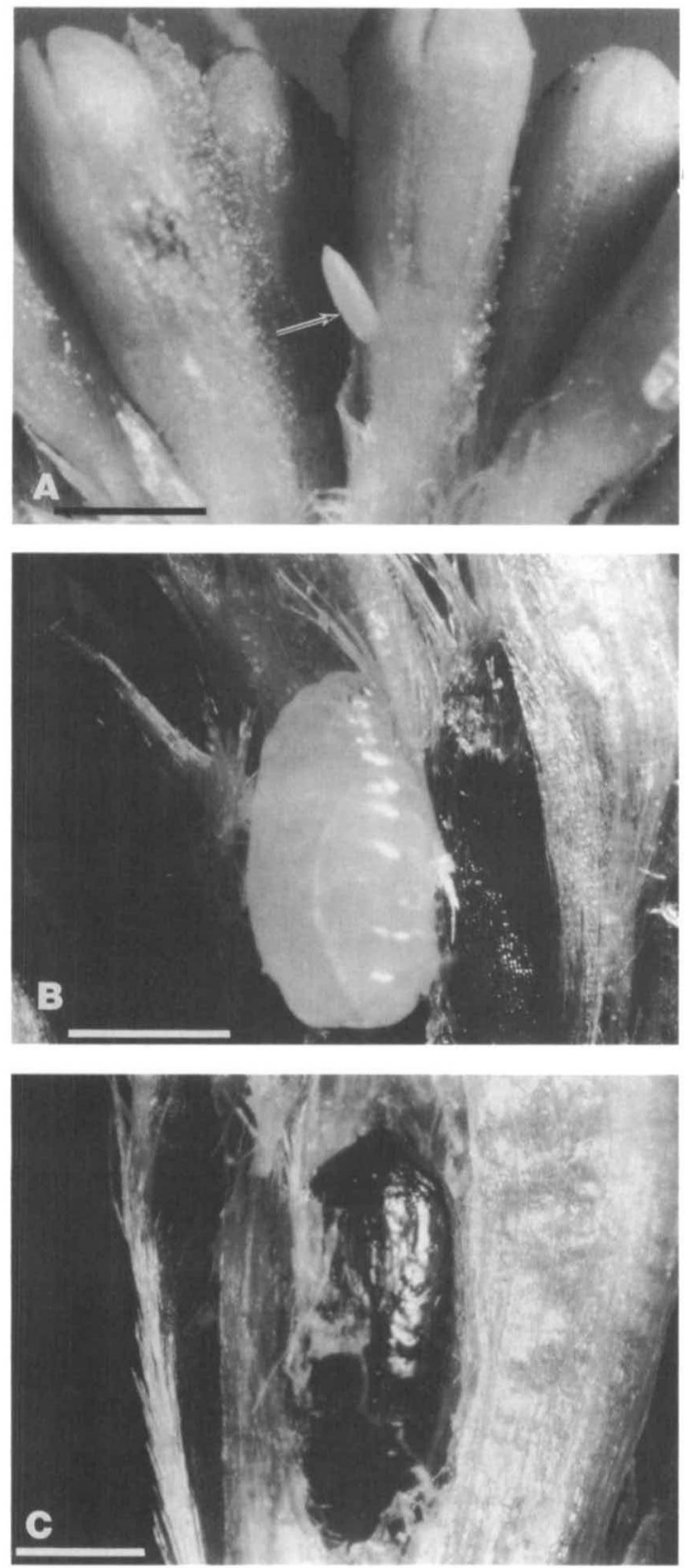

Fig. 2. Life stages of $T$. nigricornis on Encelia spp. in southern California. (A) egg, (B) 3rd instar, (C) puparia as 2 color morphs. Bars $=1 \mathrm{~mm}$.

Second Instar. Second instars continued to feed within $1-3$ additional adjacent soft achenes for the duration of this stage. Of $40 \mathrm{E}$. farinosa flower heads infested with $T$. nigricornis 2 nd instars, 4 (10\%) heads contained lst instars, and 21 (52.5\%) heads contained early 3rd instars.

Third Instar. Third instars fed on 3-5 additional adjacent achenes that were either completely destroyed or had their outer margins reduced to thin crescents of fruit coat. Larvae fed with their long axes oriented vertically and with their mouthparts directed toward the receptacle (Fig. 2B). However, when $>1$ larva (2-7) was present in a flower head, they were oriented with their long axis nearly parallel to the receptacle.

A few (7\%) 3rd instars fed on and later formed puparia atop the receptacle. In 6 of 15 cases (40\%), these latter larvae slightly scored the receptacle after destroying the achene in which they fed before moving to adjacent achenes. In the medium-size, elongate heads of E. fructescens, very few (0.8\%) 3rd instars were found feeding on the receptacle. Most larvae in $E$. fructescens were found between 0.6 and $2.0 \mathrm{~mm}$ above the receptacle. In the large heads of E. virginensis, few (1.2\%) larvae fed on the receptacle and the majority were found at various levels, between 0.8 and $3.2 \mathrm{~mm}$ above the receptacle. Most $(90 \%)$ of the larvae and puparia in the small heads of $H$. acradenius were found at the surface of the receptacle. Consequently, the receptacle was scored $57 \%$ of the time. In the medium-size heads of $V$. deltoidea, larvae were found between 0 and $1.2 \mathrm{~mm}$ above the receptacle; however, no scoring of the receptacle was observed. The occasional scoring of the receptacle by $T$. $n i$ gricornis produced small cavities $0.5-0.7 \mathrm{~mm}$ in width; $0.5 \mathrm{~mm}$ in depth $(n=12)$.

Puparium. The puparium was formed in the feeding cavity among the damaged achenes and their remnants, which were lightly glued to the puparium (Fig. 2C). In the medium-size heads of $E$. farinosa, most $(81 \%)$ puparia were found between 0.4 and $1 \mathrm{~mm}$ above the receptacle. When $>1$ larva was present in a flower head, the puparia either were separated by 1 to several achenes or formed contiguously. The size of the puparium varied among host-plant species (Table 2). The smallest puparia were found in the flower heads of $H$. acradenius; whereas, the largest puparia were found in flower heads of $E$. fructescens. In medium-size hosts the size of puparia varied with the density of larvae per flower head (Table 3). In E. fructescens, puparium width was smaller on average in flower heads infested with 4-5 larvae than with just 1 (Table 3). However, no correlation was found between larval density and puparium size in E. fructescens (Table 3). In E. farinosa, no difference in the sizes of puparia was detected between flower heads with 1-3 individuals. Flower heads with 4-5 puparia were rare in the medium-size heads of $E$. farinosa (Table 3). In E. virginensis, no differences in puparium size were observed in flower heads with 1 or 2 individuals and flower heads with 4-9 individuals (Table 3).

Analysis of Infestation. The number of $T$. $n i$ gricornis larvae that can feed and complete their development in the same flower head was found to vary among different host plants and was proportional to the size $(R=0.47)$ and the dry weight ( $R=0.28$ ) of the flower heads. The small flower heads of $H$. acradenius contained mainly $(89.5 \%)$ 1 larva per head (Table 6). Only $7.5 \%$ of heads of 
Table 5. Courtship and mating behaviors of $T$. bisetosa and $T$. nigricornis

\begin{tabular}{|c|c|c|}
\hline Behavior & T. bisetosa & T. nigricomis \\
\hline \multicolumn{3}{|c|}{ Courtship } \\
\hline Time of display & 1500-1900 hours & 0900-1400 hours \\
\hline Frequency of wing extensions & 2 beats/s & 1 beat/s \\
\hline Degree of arc for male wing display & Wide $\left(\approx 30^{\circ}\right)$ & Narrow $\left(\approx 10^{\circ}\right)$ \\
\hline \multicolumn{3}{|c|}{ Copulation } \\
\hline $\begin{array}{l}\text { Position of male } \\
\text { Duration of copulation }\end{array}$ & $\begin{array}{l}\text { Head behind thorax of female } \\
7 \text { and } 8 \min (n=2)\end{array}$ & $\begin{array}{l}\text { Head above thorax of female } \\
13,15,20 \text {, and } 25 \min (n=4)\end{array}$ \\
\hline
\end{tabular}

H. acradenius contained 2 larvae per head and even fewer (3\%) had 3 or 4 larvae (Table 6). The number of $T$. nigricornis larva(e) per head in the hosts with medium-size flower heads ( $E$. farinosa, E. fructescens, and $V$. deltoidea) were as follows: $71-75 \%$ of the flower heads contained 1 larva, 19$24 \%$ had 2 larvae, and 3-6\% had 3-5 larvae (Table $6)$. In the large flower heads of $E$. virginensis, the number of larva(e) per head were distributed as follows: $\approx 24 \%$ of the flower heads had 1 larva, $\approx 48 \%$ had 2 or 3 larvae, $\approx 18 \%$ had 4 or 5 larvae, $\approx 7 \%$ had 6 or 7 larvae, and $\approx 4 \%$ had 8 or 9 larvae (Table 6). Trupanea nigricornis females apparently adjusted the number of eggs laid relative to the size of the flower heads.

A single larva of $T$. nigricornis damaged from 3 to 19 achenes, depending on the host-plant species (Table 4). By the time a T. nigricomis larva completed its development, it had destroyed an average of 9 achenes in $E$. farinosa, 8 achenes in $E$. virginensis and $E$. fructescens, 8.5 achenes in $V$. deltoidea, and 7 achenes in Haplopappus acradenius (Table 4).

The percentage of achenes damaged in a flower head by a single $T$. nigricornis larva was proportional to the size of the flower head. Damage was highly correlated with the diameter $(R=0.91)$ and the dry weight $(R=0.86)$ of the flower heads of T. nigricornis hosts. Percentage of achenes damaged by a single larva was highest in the smaller flower heads of $H$. acradenius $(51 \%)$, which contained the fewest achenes per flower head, and lowest in the large flower heads of E. virginensis (10.3\%), which contained the most achenes per flower head (Table 4). Achene damage ranged between 18 and $24 \%$ in medium-size flower heads of
E. farinosa, V. deltoidea, and E. fructescens (Table 4).

Courtship and Mating Behaviors. Courtship and mating behaviors are summarized in Table 5 . In the laboratory, males displayed from 1500 to 1900 hours (PDST) $(n=60)$. Courtship displays included abdominal pleural distension and asynchronous supination with the head and thorax raised while moving about on plants provided in cages ("jump-fly" body posture, Goeden et al. [1987]). Males also supinated their wings when approaching a female; typically 2-3 times with every step forward. Males walked up and down stems while synchronously and asynchronously supinating their wings. At close proximity to females, males faced females while remaining motionless; this brief rest was accompanied with slow, alternate, wing supinations. If females remained still, males rapidly approached them with their wings supinating at an increased frequency. At a distance of $2-3 \mathrm{~mm}$, males changed their wing display. The wings were initially extended forward from a 45$50^{\circ}$ angle to an angle of $100^{\circ}$ with the long body axis, elevated, then lowered while being moved posteriorly. Males moved toward females, continuing their wing display, until their mouthparts made contact. Females stepped backward from advancing males or raised 1 or both forelegs and pushed males away. Male thus treated resumed circular wing motions and attempted to mount females from the side. During successful mountings, males grasped the abdominal pleura of the female with their fore and midlegs, while the hind legs hung down and the tarsi touched the substrate. Unsuccessful mountings resulted from females pushing the male away with their hind legs or curving the

Table 6. Frequency distributions of larvae of $T$. nigricornis in 5 different host plant species

\begin{tabular}{|c|c|c|c|c|c|}
\hline \multirow{2}{*}{$\begin{array}{l}\text { No. larvae } \\
\text { per head }\end{array}$} & \multicolumn{5}{|c|}{ Count $(\%)$} \\
\hline & E. virginensis & E. farinosa & E. fructescens & H. acradenius & V. parishii \\
\hline 1 & $44(23.7)$ & $274(71.4)$ & $210(75.5)$ & $60(89.5)$ & $65(73)$ \\
\hline 2 & $53(28.5)$ & $86(22.4)$ & $53(19.4)$ & $5(7.5)$ & 2]. $(23.6)$ \\
\hline 3 & 36 (19.4) & $22(5.7)$ & $13(4.7)$ & $1 \quad(1.5)$ & $2(2.3)$ \\
\hline 4 & $18 \quad(9.7)$ & $2(0.5)$ & 0 & $1 \quad(1.5)$ & 1. $(1.1)$ \\
\hline 5 & $15(8.1)$ & 0 & $1 \quad(0.4)$ & 0 & 0 \\
\hline 6 & $9(4.8)$ & 0 & 0 & 0 & 0 \\
\hline 7 & $4 \quad(2.1)$ & 0 & 0 & 0 & 0 \\
\hline 8 & $4 \quad(2.1)$ & 0 & 0 & 0 & 0 \\
\hline 9 & $3(1.6)$ & 0 & 0 & 0 & 0 \\
\hline
\end{tabular}


oviscape downward so that its apex was firmly pressed to the substrate. Such unsuccessful mounting attempts lasted $5-30 \mathrm{~s}(n=10)$.

Mating was observed only in the laboratory. The durations of 4 insectary matings were 13, 15, 20, and $25 \mathrm{~min}$. Mating ended when males dismounted. In 2 of 4 instances, males turned and assumed an end-to-end position while withdrawing, then recoiling the aedeagus. Males and females stood apart and groomed after uncoupling.

\section{Discussion}

The working hypothesis on which these comparisons were based was that $T$. bisetosa and $T$. nigricornis are cryptic, sympatric, probably sibling species. They are taxonomically close as adults (Foote et al. 1993), nearly indistinguishable as immatures (Knio et al. 1996), but T. bisetosa has a limited host range that does not overlap with the wide host range of $T$. nigricornis. This suggests that these 2 species either once shared a common ancestor and diverged in their host ranges or 1 species evolved from the other. Zwölfer $(1979,1983)$ developed hypotheses concerning host-range expansion or shifting for nonfrugivorous tephritids. He divided the ecological constraints of host-range changes into 2 categories, extrinsic and intrinsic factors. Extrinsic factors involve the adult stage and include behavioral acceptance of new hosts, dispersal to new hosts, timing the life cycle to include new hosts, and overcoming ovipositional constraints in new hosts. Intrinsic factors concern the immature stages and include enemy-free space, intra- and interspecific competition, nutritional suitability, and timing of diapause (if any).

There were few intrinsic factors that showed differences between these 2 species. The morphological similarity between $T$. nigricornis and T. bisetosa immature stages shows that the ability to feed and survive on new hosts does not present a major barrier to host-range expansion of host-shifting by either species (Knio et al. 1996). T. nigricornis and T. bisetosa larvae fed in flower heads in a similar manner, as 3rd instars. However, 1st instars of $T$. bisetosa only tunneled and fed in corollas; whereas 1st instars of $T$. nigricornis attacked corollas and $\geq 1$ ovules or soft achenes. Second instars of T. $n i$ gricornis fed in the soft achenes, whereas 2nd instars of $T$. bisetosa continued to feed in the corollas, but close to the achene-corolla junction. Third instars of both species fed and destroyed several adjacent achenes. When $>1$ larva of either species were present in a flower head, they were usually located centrally but fed on different achenes and were separated by 1 or several achenes.

Scoring the receptacle during feeding by 3rd instars was observed only with $T$. nigricornis. The occasional scoring of the receptacle in $T$. nigricornis appears different from that reported for Paracantha gentilis Hering (Headrick and Goeden 1990). Third instars of $P$. gentilis scored the recep- tacle at the center of the flower heads when they occurred at high densities ( $\geq 3$ larvae per head). Scoring of the receptacle produced 'cup-like depressions' with a diameter of $1.6 \mathrm{~mm}$ and a depth of 1-2 $\mathrm{mm}$. These depressions provided the larvae with enough sap and nutrients to complete their development at high larval densities. A T. nigricornis larva produced 3-4 small cavities instead of 1 large cavity and the cavities were not located at the center of the flower head, but were found at the base of 3-4 achenes in which a larva had fed. Occasional scoring of the receptacle of $T$. nigricornis was observed in heads with 1 larva as well as in heads with 2-4 larvae. Hence, this process in $T$. nigricornis is not related to larval density and may not serve the same function as in $P$. gentilis.

Differences in extrinsic factors between these 2 species include oviposition behaviors and courtship and mating behaviors. The eggs of T. bisetosa were deposited loosely among the florets, but those of T. nigricornis always had their posterior end inserted in a corolla or ovule. Thus, the females of T. nigricomis pierced the floret tissues during oviposition, whereas those of $T$. bisetosa avoided piercing the florets of $H$. annuus, which exudes a sticky resin when injured. If the tissues of $H$. annuus were pierced then either the adult became trapped in the resins or the eggs were smothered and did not eclose. Thus, behavioral differences in oviposition have evolved between these 2 species because of the physical constraints of the larval resource.

The percentage of flower heads infested by $T$. bisetosa was lower on average than the percentage flower heads infested by $T$. nigricornis, with the exception of $H$. acradenius. However, the number of larvae per flower head was higher in the large flower heads of $H$. annuus, the main host of $T$. bisetosa, than in most hosts of $T$. nigricornis, with the exception of $E$. virginensis, which also had large flower heads.

Percentage of infestation by $T$. bisetosa varied during the year. Infestations of $H$. annuus flower heads by $T$. bisetosa were highest late in the fall, when the densities of the sunflower heads started to decrease. Infestations were low to moderate in the spring, depending on the availability of soil moisture, and was low during the typically hot, dry summer. Unlike $H$. annuus, the host plants of $T$. nigricornis each bloom for 2-3 mo in the spring, with the exception of $H$. acradenius which blooms for a short period (1-2 months) in the fall. Percentage of infestation by $T$. nigricornis generally was higher than that of T. bisetosa on $H$. annuus, as the hosts of $T$. nigricornis were only available for short periods of time. The variation in percentage of infestations observed within host plants of T. nigricornis can be accounted for by host-plant and conspecific population densities at different locations, but not to seasonal differences as noted for $T$. bisetosa, as the host plants of $T$. nigricornis mainly bloomed only either in the spring or fall. 
Thus, temporal separation between the cooccurrence of these 2 species varies with host-plant phenology.

Spatial separation between these 2 species in areas of close sympatry appears to be related to hostplant cues and timing of behavioral events, rather than naturally occurring physical barriers. $T$. nigricornis males displayed in the mornings and T. bisetosa males displayed in the afternoon in all observations. All courtship and mating behavior took place only on the host plants for each of these species in field observations. This included areas of close sympatry, for example, where $E$. farinosa and $H$. annuus plants grew side by side. This spatial separation may be important in promoting reproductive isolation between these 2 species. Restriction of the meeting of potential mates and mating on the host plant is a required attribute for models of sympatric speciation (Bush 1969, 1975), and sympatric speciation is facilitated when host preference is associated with mate selection (Bush 1969, Diehl and Bush 1988). Only subtle differences were observed in other courtship and mating behaviors, for example in the male wing displays. Wing displays may provide for visual discrimination by females among males to prevent mating mistakes with closely related or sympatric species (Tauber and Tauber 1967, Burk 1981, Headrick and Goeden 1995).

\section{Acknowledgments}

We thank F. L. Blanc, J. A. Teerink, and 2 anonymous reviewers for their helpful reviews of earlier drafts of the manuscript.

\section{References Cited}

Burk, T. 1981. Signaling and sex in acalyptrate flies. Fla. Entomol. 64: 30-43.

Bush, G. L. 1969. Sympatric host race formation and speciation in frugivorous flies of the genus Rhagoletis (Diptera: Tephritidae). Evolution 23: 237-251.

1975. Sympatric speciation in phytophagous parasitic insects, pp. 187-207. In P. W. Price [ed.], Evolutionary strategies of parasitic insects and mites. Plenum, New York.

Cavender, G. L., and R. D. Goeden. 1982. Life history of Trupanea bisetosa (Diptera: Tephritidae) on wild sunflowers in southern California. Ann. Entomol. Soc. Am. 75: 400-406.
1983. On distinguishing Trupanea bisetosa (Coquillett) from T. nigricornis (Coquillett) (Diptera: Tephritidae). Proc. Entomol. Soc. Wash. 85: 275-281.

Diehl, S. R., and G. L. Bush. 1988. The role of habitat preference in adaptation and speciation, pp. 345365. In D. Otte and J. A. Endler [eds.], Speciation and its consequences. Sinauer, Sunderland, MA

Foote, R. H., F. L. Blanc, and A. L. Norrbom. 1993. Handbook of the fruit flies (Diptera: Tephritidae) of America north of Mexico. Cornell University Press, Ithaca, NY.

Goeden, R. D. 1985. Host-plant relations of Trupanea spp. (Diptera: Tephritidae) in southern California. Proc. Entomol. Soc. Wash. 87: 564-571.

1992. Analysis of known and new host records for Trupanea from California (Diptera: Tephritidae). Proc. Entomol. Soc. Wash. 94: 107-118.

Goeden, R. D., T. D. Catadal, and G. A. Cavender. 1987. Life history of Neotephritis finalis (Loew) on native Asteraceae in southern California (Diptera: Tephritidae). Proc. Entomol. Soc. Wash. 89: 552-558.

Headrick, D., and R. D. Goeden. 1990. Resource utilization by larvae of Paracantha gentilis (Diptera: Tephritidae) in capitula of Cirsium califormicum and C. proteanum (Asteraceae) in southern California. Proc. Entomol. Soc. Wash. 92: 512-520.

1995. Reproductive behaviors of California fruit flies and the classification and evolution of tephritid (Diptera) mating systems. Studia Dipterologica 1(2): 194252.

Knio, K. M., R. D. Goeden, and D. H. Headrick. 1996. Descriptions of the immature stages of $T$. $n i$ gricornis (Coquillett) and $T$. bisetosa (Coquillett) (Diptera: Tephritidae) in southern California. Ann. Entomol. Soc. Am. 89: (in press).

Tauber, M. J., and C. A. Tauber. 1967. Reproductive behavior and biology of the gall-former Aciurina ferruginea (Doane) (Diptera: Tephritidae). Can. J. Zool. 45: 907-913.

Tsiropoulos, G. J. 1978. Holidic diets and nutritional requirements for survival and reproduction of the adult walnut husk fly. J. Insect Physiol. 24: 239-242.

Zwölfer, H. 1979. Strategies and counterstrategies in insect population systems competing for space and food in flower heads and galls. Fortschr. Zool. 25: 331-353.

1983. Life systems and strategies of resource exploitation in tephritids, pp. 16-30. In R. Cavalloro [ed.], Proc. CEC/IOBC International Symposium A. A. Balkema, Rotterdam.

Received for publication 5 October 1994; accepted 2 October 1995 